\section{Jolanta Judyta Pudełko PDDM}

Papieski Wydział Teologiczny, Warszawa

judyta.pd@gmail.com

DOI: http://dx.doi.org/10.12775/BPTh.2017.013
Biblica

et

Patristica

Thoruniensia

10 (2017) 2: 263-283

ISSN (print) 1689-5150

ISSN (online) 2450-7059

\title{
Dawid jako organizator kultu w Pochwale Ojców (Syr 47,8-10)
}

\section{David as the Cult Organizer in the Praise of the Ancestors (Sir 47:8-10)}

Streszczenie. Pochwała Ojców (Syr 44-49) zawiera prezentację dziejów biblijnego Izraela, jako obraz działania Boga w historii. Mędrzec przedstawia według własnych kryteriów najważniejszych i pozytywnych bohaterów tej historii. Dawid, opisany w Syr 47,1-11, jest jednym z najważniejszych bohaterów Starego Testamentu. Działalność Dawida jako króla zostaje przedstawiona przez Syracha przede wszystkim jako inicjatora kultu w Jerozolimie (Syr 47,8-10). Mędrzec korzystał tu z „kultycznego” obrazu Dawida, obecnego w 1 Krn. Jednocześnie obraz Dawida włącza się w charakterystyczną dla Pochwały Ojców koncepcję dziejów i przymierza. Dawid staje się zapowiedzią postaci arcykapłana Szymona (Syr 50,1-24), który w czasach Syracha był jedynym znakiem przymierza oraz pośrednikiem między Bogiem i Jego ludem.

Summary. The Praise of the Ancestors (Sir 44-49) includes the presentation of the history of biblical Israel as an exemplification of God's working in history. The sage presents the most important and positive heroes of this history according to his own criteria. David, described in Sir 47:1-11, is one of the most important Old Testament heroes. His activity as a king is presented by Sirach first of all as that of an initiator of Jerusalem cult (Sir 47:8-10). The sage employed the "cultic" image of David, present in Chronicles 1. The image of David is also integrated with the idea of history and covenant characteristic of the Praise of the Ancestors. David becomes a forerunner of the high priest Simon, who was, in the times of Sirach, a sole sign of the covenant as well as the mediator between God and his people.

Słowa kluczowe: Księga Syracha; Pochwała Ojców; Księgi Kronik; Dawid; kult; muzyka liturgiczna.

Keywords: Book of Sirach; Praise of the Ancestors; Books of Chronicles; David; cult; liturgical music. 
$\mathrm{D}$ awid jest jednym z najważniejszych bohaterów biblijnych, którego postać została opisana dość obszernie na kartach Starego Testamentu. Jego historia, droga do tronu i zbudowania najważniejszej biblijnej dynastii została opisana zarówno w 1 Sm 16-2 Krl, jak i w 1 Krn 11-29. Jego imię zostaje związane z wieloma psalmami $(3-41 ; 51-70 ; 72,20 ; 138-145)$, jest też obecny w refleksji proroków (np.: Iz 16,5; Jr 23,5; Ez 37,24-25; Am 9,11). Biblia opisuje niezwykłe i burzliwe dzieje Dawida jako najmłodszego syna Jessego, pasterza, muzyka i śpiewaka, dzielnego wojownika i króla. Pomimo swej ludzkiej słabości jawi się jako wierny miłośnik YHWH, do czego nawiązuje jego imię (rdzeń דוד) w zależności od wokalizacji oznacza zarówno „Dawid” (דרזיד), jak i „umiłowany”(דוֹד). Mędrzec okresu hellenistycznego (II w. przed Chr.), Syrach, umieszcza szkic postaci Dawida w swojej mądrościowej refleksji nad historią - Pochwała Ojców (Syr 44-49). Mając do dyspozycji obszerny materiał spisanych tradycji dokonał jej interpretacji, wyłaniając to, co w długiej historii Dawida było jego zdaniem najistotniejsze.

\section{Kontekst Syr 47,8-10}

Cała Księga Syracha, w wielości swych mądrościowych maksym i perykop, stanowi syntezę wiary i tradycji biblijnego Izraela, na co zwrócił uwagę już w Prologu tłumacz greckiej wersji księgi (por. Prolog 7-14). Jednocześnie Pochwała Ojców (Syr 44-50) to szczególne świadectwo interpretacji historii ludu Izraela, która stały się historią zbawienia. A.A. Di Lella uważa, że oprócz rozdziałów 44-50, które w znalezionym ms B w genizie kairskiej zamieszczone były pod tytułem Pochwała Ojców, księga objawia brak szczególnego uporządkowania czy klarowności ${ }^{1}$. Zatem rozdziały 44-50 Księgi Syracha tworzą literacką i tematyczną jedność, co wykazuje większość propozycji strukturyzacji księgi. H.W. Jüngling zebrał różne propozycje strukturyzacji Księgi, które konsekwentnie podkreślają odrębność Syr 44-50. Koncentrują się one wokół tematu wypełnienia zaleceń mądrości w życiu wybitnych jednostek ${ }^{2}$. O ile początek tej sekcji jest powszechnie przyjęty i wskazuje się go w Syr $44,1^{3}$, o tyle zakończe-

1 Por. P.W. Skehan, A.A. Di Lella, The Wisdom of Ben Sira. A New Translation with Notes, 4; por. J. Marböck, "Structure and Redaction History in the Book of Ben Sira. Review and Prospects", 63.

2 Por. H.W. Jüngling, „Der Bauplan des Buches Jesus Sirach“, 97. Por. J. Marböck, "Structure and Redaction History in the Book of Ben Sira. Review and Prospects", 61-79.

3 Zob. np.: R. Smend, Die Weisheit des Jesus Sirach erklärt, xxxiv; P.W. Skehan, A.A. Di Lella, The Wisdom of Ben Sira, 4-6; J.D. Harvey, „Toward a Degree of Order in Ben 
nie stanowi kwestię dyskusyjną. Pojawia się pytanie o relację i ewentualną jedność tematyczną rozdziałów 44-49 z tekstem sławiącym arcykapłana Szymona (50,1-21), który żył w czasie bliskim autora księgi ${ }^{4}$. Jednak komentatorzy nie są do końca zgodni w opiniach. Zakończenie tekstu miałoby miejsce w rozdziale 50, albo w wersecie 29, 26 lub $21^{5}$. R. Smend natomiast ustala granicę tekstu na Syr 49,16, oddzielając perykopę o arcykapłanie Szymonie od Pochwały Ojców ${ }^{6}$. Fragment Syr 49,14-16 wydaje się konkluzją wcześniejszych tekstów, które traktowały o biblijnych bohaterach z przeszłości. Chronologiczny ciąg zatrzymuje się po przedstawieniu Nehemiasza $(49,13)$ i w ww. 14-16 następuje zaskakujący powrót do początków. Pojawia się wcześniej wymieniany w 44,16 Henoch, Józef, Sem, Set oraz Enosz (w tekście hebrajskim) a na samym koń-

Sira’s Book”, ZAW 105 (1993) 61; H.W. Jüngling, „Der Bauplan”, 105. Nie brakuje jednak autorów, którzy za wprowadzenie do Pochwały ojców uważają wcześniejszy tekst o stworzeniu (42,15-43,33). Zob. np.: N. Peters, Das Buch Jesus Sirach oder Ecclesiasticus. Übersetzt und erklärt (Exegetisches Handbuch zum Alten Testament 25; Münster 1913) xli; C. Spicq. L'Ecclésiastique (SB[PC]; Paris 1951) 553-554; A. Minissale, Siracide (Ecclesiastico). Versione - Introduzione - Note (Roma 1980) 10; G. Sauer, Jesus Sirach / Ben Sira (ATD Apokryphen 1; Göttingen 2000) 34-35. W. Roth ("On the Gnomic-Discursive Wisdom of Jesus Ben Sirach”, Semeia 17 [1980] 60) wyodrębnia siedem części księgi, z której każda rozpoczyna się perykopą na temat mądrości. Pochwała Ojców wchodzi w skład większej jednostki Syr 38,24-50,29. Natomiast według T.R. Lee (Studies in the Form of Sirach 44-50 [SBL Dissertation Series 75; Atlanta 1986] 6), Syr 42,15-43,33 oraz 44,1-50,24 stanowią dwie oddzielne perykopy, które posiadają paralelne odniesienia.

4 Niektórzy identyfikują go z żyjącym na przełomie IV i III w. przed Chr. Szymonem I, który został nazwany przez Józefa Flawiusza „Szymonem Sprawiedliwym”, zakładając, iż Syn Syracha nie znał osobiście opisywanego arcykapłana, nawet jeśli barwne opisy wskazywałyby na naocznego świadka. Por. np.: J.C. VanderKam, From Joshua to Caiaphas. High Priest after the Exile (Minneapolis - Assen: Royal Van Gorcum 2014) 149-151; H. Drawnel, „Władza arcykapłana w Izraelu we wczesnym okresie hellenistycznym: pomiędzy historią a kapłańską ideologią dydaktyczną", Polityka a religia (red. P. Jaroszyński i in.) (Lublin 2007) 306-307, przyp. 7. Inni natomiast, utożsamiają opisywaną przez Syna Syracha postać z arcykapłanem Szymonem II, wnukiem Szymona I, który pełnił swój urząd na przełomie III i II w. przed Chr. (ok. 210 - 196), co pozwalałoby autorowi księgi być naocznym świadkiem jego dokonań. Por. np. J. Ciecieląg, Żydzi w okresie drugiej świątyni 538 przed Chr.-70 po Chr. (Kraków: Universitas 2011) 165-167; Skehan - Di Lella, The Wisdom of Ben Sira, 550.

5 Por. Peters, Das Buch Jesus Sirach, 553-554; Roth, "On the Gnomic-Discursive Wisdom”, 60; Harvey, „Toward a Degree of Order”, 61; Jüngling, „Der Bauplan”, 105; Spicq, L'Ecclésiastique, 553-554; Minissale, Siracide, 9-10; Skehan - Di Lella, The Wisdom of Ben Sira, 5; Sauer, Jesus Sirach, 34-35.

6 Smend (Die Weisheit, 474) stwierdza: "Um das Lob der Väter abzuschlissen und es zugleich gegen das Lob des Simon abzugrenzen, biegt Sirach jetzt auf die Urzeit zurück." 
cu, nie wymieniany wcześniej w Pochwale Ojców Adam7. Kończy się tu opowieść o „ojcach z przeszłości” i dlatego pojawia się powrót do początku, aby potem podjąć nowy etap, bliższej historii, która dotyczy arcykapłana Szymona. W przedstawieniu „ojców z przeszłości” sam autor dokonał selekcji postaci i jednocześnie uwypuklił te aspekty ich życia i działania, które wydawały się mu szczególnie ważne w tej świętej historii. W Pochwale Ojców Dawid jest wzmiankowany kilka razy, również wtedy, gdy autor przedstawia inne osoby. W 45,25 pochwała Mojżesza, Aarona i Pinchasa zostaje zestawiona z przyszłym przymierzem Dawidowym ${ }^{8}$. Prezentując późniejszych królów Judy, Syrach odnosi ich do Dawida, czy domu Dawidowego, jako wyraźnego wzoru i punktu odniesienia (zob. 48,16.22; 49,4; 51,12H) . Jednak sam opis postaci Dawida znajduje się w 47,1-11. Po przedstawieniu proroka Natana, działającego w czasach Dawida $(47,1)$, Syrach przechodzi do samej osoby najmłodszego syna Jessego. Po wprowadzeniu $(47,2)$, następuje pierwsza część opisu Dawida, związana z czasem poprzedzającym jego panowanie, tak zwana „prehistoria” (47,3-7), w której uwypukla się jego męstwo, odwagę, zwycięskie bitwy, które przynosiły mu wielką sławę ${ }^{10}$. Syr 47,8 opis dotyczy postawy Dawida wobec Boga, chwałę i uwielbienie, jakie dokonywały się poprzez Jego modlitwę. Zaowocowało to inauguracją kultu YHWH w miejscu, gdzie w Jerozolimie została przeniesiona Arka Przymierza, a Dawid ustanowił odpowiedzialnych za liturgię i piękno jej przebiegu $(47,9-10)^{11}$. Opis Dawida kończy się wzmianką o wierności Boga wobec Dawida. Jego grzechy zostały mu wybaczone, a przymierze z Bogiem jeszcze bardziej ugruntowane, utwierdzając na wieki jego panowanie $(47,11)^{12}$. Struktura tekstu o Dawidzie w Syr 47,1-11 sugeruje, iż w opinii Syracha najważniejszymi dokonaniami panowania Dawida były te, związane z kultem. Czy faktycznie tak jest wykaże analiza fragmentu Syr 47,8-10, który tego dotyczy.

7 Por. Lee, Studies, 10-11,

8 Por. G.G. Xeravits, “The Figure of David in the Book of Ben Sira”, Henoch 23 (2001) 1 3, 28; M. Marko, "David in the Wisdom of Ben Sira" SJOT 25/1 (2011) 31.

9 Xeravits, "The Figure of David in the Book of Ben Sira", 28-29.33-35.

10 Por. A. Demitrów, Quattro oranti nell'Elogio dei Padri (Sir 44-49). Studio dei testi e delle tradizioni (Opolska Biblioteka Teologiczna 124; Opole 2011) 274-308; Xeravits, "The Figure of David in the Book of Ben Sira", 29-30.

11 Według struktury zaproponowanej przez: Xeravits, "The Figure of David in the Book of Ben Sira”, 29, opis w ww. 8-10 jest to czas aktywności Dawida, po przejęciu przez niego władzy.

12 Por. W.O.E. Oesterley, The Wisdom of Jesus the Son of Sirach or Ecclesiasticus. Revised Version with introduction and notes, (Cambridge: Cambridge University Press 1912) 321. 


\section{Wersje tekstualne Syr 47,8-10}

Księga Syracha posiada zróżnicowanie pod względem tekstualnym. Choć sama księga powstała w języku hebrajskim, to ten tekst przez wiele lat był uważany za zaginiony. Odkrycia zapoczątkowane w 1896 r. w genizie kairskiej wydobyły na światło dzienne rękopisy hebrajskie zawierające $2 / 3$ całej księgi, w różnych odpisach. Niektóre z fragmentów posiadają bardzo dobrze zachowane świadectwa tekstu hebrajskiego, choć ich datacja wskazuje na XI-XII w. po Chr ${ }^{13}$. Tekst hebrajski Syr 47,8-10 (H) pochodzi z rękopisu B, dwunastowiecznych fragmentów, zawierających Syr 30,11-33,3; 35,11-38,27b; 39,15c-51-30, odnalezionych $\mathrm{w}$ genizie kairskiej, zapisanych w kolumnach, bez odstępów między wyrazami i zdaniami (sposób stychometryczny) ${ }^{14}$. Tekst Syr 47,8-10 H z genizy kairskiej jest dość znacznie uszkodzony ${ }^{15}$ :

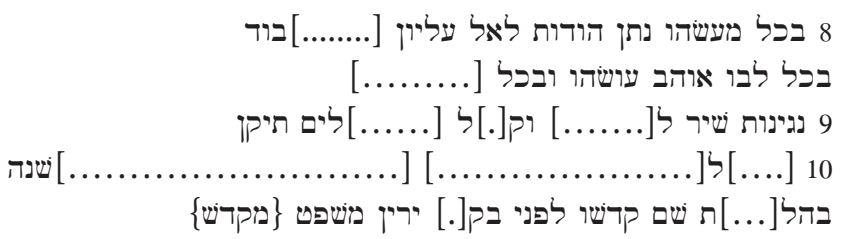

A. Demitrów, dokonując analizy Syr 47,8-9, odnosząc się do sugestii innych autorów, zaproponował rekonstrukcję tekstu hebrajskiego ${ }^{16}$. Syr 47,8a(H) nie posiada uszkodzeń i nie wymaga rekonstrukcji: בכל מעשהו נתן הודות ,W każdym swoim czynie składał uwielbienie". Kolejna cześć wersetu 47,8b jest usz

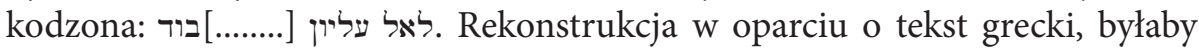

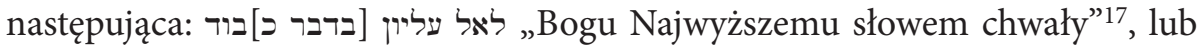

13 Por. Skehan - Di Lella, The Wisdom of Ben Sira, 51; P.C. Beentjes (ed.), The Book of Ben Sira in Hebrew. Text Edition of All Extant Hebrew Manuscripts and a Synopsis of All Parallel Hebrew Ben Sira Texts (VT.S 68; Leiden - New York - Köln: Brill 1997) 5-6.

14 Ocenę ms B prezentuje A.A. Di Lella, The Hebrew Text of Sirach. A Text-Critical and Historical Study, (StCL 1; London - Paris: Mouton \& Co. 1966) 148: "Unless the contrary is demonstrated, the Geniza Mss contain the original text or something very near to original of Ben Sira".

15 Beentjes (ed.), The Book of Ben Sira in Hebrew, 84; por. C. Mopsik, La Sagesse de Ben Sira (Lagrasse: Verdier 2003) 297.

16 Szczegółową rekonstrukcję podaje: Demitrów, Quattro oranti nell'Elogio dei Padri (Sir 44-49), 248-259.

17 Por. M.S. Segal (ed.), ספר בן סירא השלם [Sēper ben-Sîrāhhaššālēm] (Jerusalem: Bialik Institute 197233) 324 ; E.S. Hartom, החיצונים הספרים) בן סירא מתרגם בחלקו ומפרשר (Tel Aviv 1963) 177. 
Bogu Najwyższemu słowami chwały”18. Werset 47,8cd

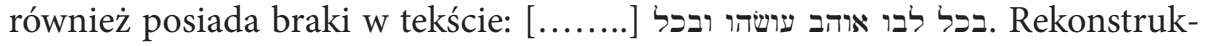

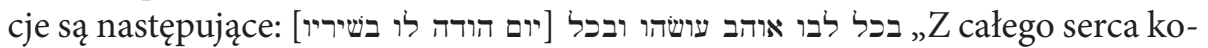
chał swojego Stwórcę i każdego dnia wielbił Go swoimi pieśniami” lub w 47,8d można to oddać następująco: ובכל [יום הללו בשיר] "każdego dnia wychwalał Go pieśnią"19. Syr 47,9ab również jest uszkodzony: נגינות שיר ל[...] וק[.]ל [...]לים תיקן. Ten tekst można zrekonstruować w następujący sposób: Instrumenty muzyczne przed oltarzem i dźwięk psalmów dla harf ustanowił”20. W 47,10ab prawie cały stych jest uszkodzony: שנה[...] [...] [ל] [...]. Odnosząc się do innych wersji (greckiej, syryjskiej i łacińskiej) niektórzy uczeni zaproponowali następującą rekonstrukcję 47,10a: DDał świętom splendor”21. W 47,10b figuruje jedynie końcowe słowo w stychu. Stąd pojawiły się różne propozycje rekonstrukcji, wychodząc od tekstu greckiego $\mathrm{w}$ porównaniu $\mathrm{z}$ tekstem syryjskim ${ }^{22}$. Jedna z propozycji 47,10b brzmiałaby następująco: ויתקן מועדים שנה ב] [ ו ש ustanowił coroczne czasy święte" $23.47,10$ cd posiada mniej uszkodzeń, niż wcześniejsze stychy, tu-

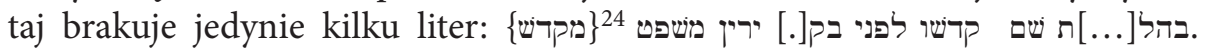
Może więc wyglądać następująco:

Kiedy wychwalał Jego święte imię, przed porankiem dając rozbrzmiewać przykazaniu”.

Przyjmując propozycje komentatorów, tekst hebrajski Syr 47,8-10 mógłby wyglądać następująco:

${ }^{8}$ W każdym swoim czynie składał uwielbienie Bogu Najwyższemu słowem chwały.

Z całego serca kochał swojego Stwórcę i każdego dnia wielbił Go swoimi pieśniami.

18 Por. Smend, Die Weisheit des Jesus Sirach erklärt, 450.

19 Por. Mopsik, La Sagesse de Ben Sira, 297 ; Demitrów, Quattro oranti nell'Elogio dei Padri (Sir 44-49), 252.

20 Por. Demitrów, Quattro oranti nell'Elogio dei Padri (Sir 44-49), 253.255.

21 Por. Segal (ed.), ספר בן סירא השלם, 324 ; Hartom, בירא מתרגם בחלקו ומפרשר, 177, Demitrów, Quattro oranti nell'Elogio dei Padri (Sir 44-49), 255-256.

22 Por. Demitrów, Quattro oranti nell'Elogio dei Padri (Sir 44-49), 256.

23 Por. Segal (ed.), ספר בן סירא השלם 177, 324; Hartom, בירא מתרגם בחלקו ומפרשר (17), Demitrów, Quattro oranti nell'Elogio dei Padri (Sir 44-49), 257.

24 Jest to glosa na marginesie tekstu, uzgadniająca znaczenie $\mathrm{z}$ wersją grecką i syryjską.

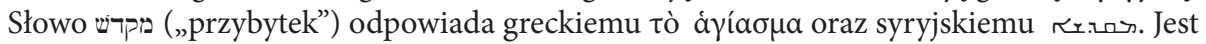
to zatem późniejsza próba harmonizacji wbrew trudniejszej lekcji פשפט („przykazanie”). Proklamacja przykazań Pana przynależało również do wielbienia Boga w kulcie. 
${ }^{9}$ Instrumenty muzyczne przed ołtarzem i dźwięk psalmów dla harf ustanowił.

${ }^{10}$ Dał świętom splendor i ustanowił coroczne czasy święte.

Kiedy wychwalał Jego święte imię, przed porankiem dając rozbrzmiewać przykazaniu.

Powyższe przedstawienie kwestii tekstu hebrajskiego wskazuje, iż tekst ten, z powodu swoich licznych uszkodzeń, nie może stanowić podstawowego tekstu do przeprowadzenia analizy egzegetycznej. Będzie on natomiast tekstem pomocniczym, z racji na przedstawienia postaci Dawida w Biblii Hebrajskiej. Podobną pomoc może stanowić wyraźnie krótsza wersja syryjska ${ }^{25}$ :

$$
\begin{array}{r}
8 \\
\text { s } 10
\end{array}
$$

${ }^{8} \mathrm{Z}$ powodu tego podniósł głos słowami dziękczynienia i chwały. I z całego serca kochał swego Stwórcę. ${ }^{9}$ I każdego dnia przed ołtarzem wytrwale wznosił swoje uwielbienia. ${ }^{10}$ Dał wspaniałe hymny na wszystkie lata.

Tekstem podstawowym będzie zatem tekst grecki Syr 47,8-10 (G), który przedstawia się następująco ${ }^{26}$ :

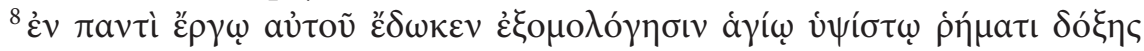

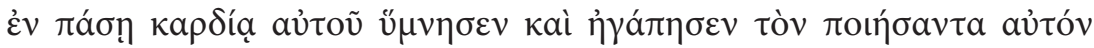

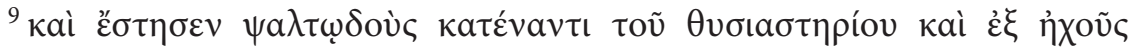

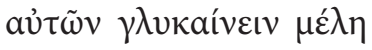

25 N. Calduch-Benages - J. Ferrer - J. Liesen (ed.), La Sabiduría del Escriba. Edición diplomática de la version siriaca del libro de Ben Sira según el Códice Ambrosiano, con tracucción española e inglesa / Wisdom of the Scribe. Diplomatic Edition of the Syriac Version of the Book of Ben Sira according to Codex Ambrosianus, with Translations in Spanish and English (Biblioteca Midrásica 26; Estella: Editorial Verbo Divino 2003) 252-255. M.S. Segal ["The Evolution of the Hebrew Text of Ben Sira", JQR 25 (1934-35) 91-149.], uważa, że tekst syryjski został przetłumaczony z trzeciej recenzji tekstu hebrajskiego, pochodzącej z II w. przed Chr. Natomiast C. Kearns [The expandet Text of Ecclesiasticus. Its Teaching on the future Life as a Clue to its Origin, A doctoral Dissertation presented to the Pontificial Biblical Commision (Roma 1951) 263], datuje ją na 75-70 r. przed Chr. Świadczy to o tym, że tekst $S$ może być bliższy hebrajskiemu oryginałowi niż obecnie posiadane fragmenty hebrajskie.

26 Septuaginta: Vetus Testamentum graece auctoritate Societatis Göttingensis editium (Göttingen: Vandenhoeck \& Ruprecht 1931-) (12/2 Sapientia Iesu Filii Sirach, ed. J. Ziegler, $\left.1965,{ }^{2} 1980\right) 357$. 


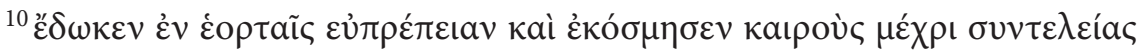

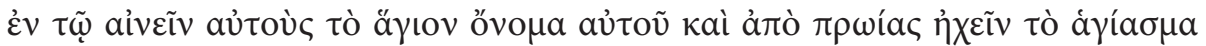

${ }^{8}$ Każdym swym czynem oddał chwałę Świętemu i Najwyższemu, słowem uwielbienia. Z całego serca swego śpiewał hymny i umiłował Tego, który go stworzył.

${ }^{9}$ Postawił przed ołtarzem śpiewających psalmy, i słodki był dźwięk ich melodii ${ }^{27}$.

${ }^{10}$ Uroczystościom nadał okazałość i uporządkował ich pory aż do najdrobniejszych szczegółów, aby wychwalali święte imię Pana i by od świtu rozbrzmiewał przybytek.

Choć wersje językowe zachowują zasadniczą zgodność przekazu i treści, można zauważyć tu pewne różnice. Tekst hebrajski w swojej rekonstrukcji jest niewątpliwie zależny od tekstu greckiego, zwłaszcza w brakujących fragmentach. Tekst hebrajski jednak, podobnie jak wersja syryjska, uwypukla działalność samego Dawida oraz chwałę, której on był sprawcą w przybytku, zarówno przez upiększenie obrzędów, jak i własny wkład przez kompozycję psalmów. Dziełem Dawida było również wprowadzenie instrumentów muzycznych do liturgii świątynnej. Tekst grecki natomiast, podkreśla inne aspekty. Dawid ustanawia śpiewaków i muzyków kultycznych i to oni są wykonawcami pieśni i upiększają obrzędy. Jest to zatem dzieło wspólnoty, a Dawid jest jej inicjatorem oraz przykładem własnej pobożności i dbałości o piękno i organizację liturgii staje się zachętą dla innych. Szczegóły uwypuklone przez te wersje znajdują odniesienie w biblijnych przekazach o organizacji kultu w Jerozolimie, co przekazuje 2 Sm oraz 1 Krn.

\section{Dawid jako inicjator liturgii Jerozolimskiej w 2 Sm oraz 1 Krn}

Historia Dawida rozpoczyna się w Księgach Samuela. Pojawia się on tam jako nic nie znaczący młodzieniec (por. 1 Sm 16,11-22), który z czasem zaczyna stawać się rywalem dla króla Saula, zwłaszcza przez pokonanie Goliata (por.

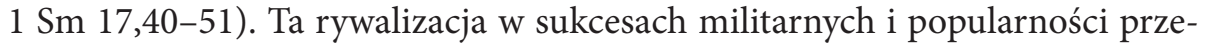
dłuża się, co wzmaga niechęć Saula i zagrożenie życia Dawida (por. 1 Sm 18,6-12; 19,1). Problem nie kończy się nawet wraz ze śmiercią Saula (por. 1 Sm 31), gdyż pojawia się walka o władzę pomiędzy Dawidem a domem Saula (por.

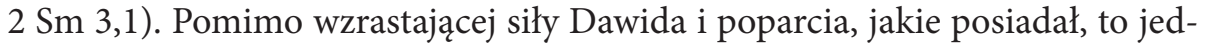
nak nie jego sukcesy militarne przyczyniły się do ostatecznego ugruntowania

27 Niektóre pomniejsze rękopisy z grupy Recenzji Lucjana dodają jeszcze 9c: „I każdego dnia będą oddawać chwałę swoimi pieśniami”. 
jego panowania. Dzieje się to dopiero wtedy, gdy po nieudanej próbie (por. 2 Sm 6,2-11) Arka Przymierza w końcu zostaje uroczyście przeniesiona do Jerozolimy (por. 2 Sm 6,12-19) i ustanowiony tam kult staje się potwierdzenie Bożego błogosławieństwa dla Dawida ${ }^{28}$. Według tego opisu, ubrany w lniany efod Dawid, dokonywał czynności kapłańskich ${ }^{29}$. Błogosławieństwo Dawida rozciąga się dalej na jego potomków, a nawet całą dynastię (por. $2 \mathrm{Sm} \mathrm{7),}$ w przeciwieństwie do Mikal, córki Saula i żony Dawida, która wzgardziwszy

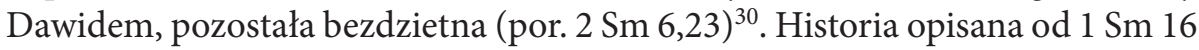
do 2 Sm 5 jest więc swoistą „drogą Dawida na tron Izraela” ${ }^{31}$. Deteronomista uwypukla tu jednak nie tyle same kwestie kultyczne, co potwierdzenie przymierza miedzy Dawidem i Bogiem oraz obietnice związane z przyszłą dynastią. Obecność Arki Pana w Mieście Dawidowym stanowi pieczęć obietnic Boga i Jego wierność przymierzu, ale podkreśla też wybranie Dawida na Bożego pomazańca i wybór Syjonu ${ }^{32}$. Bardzo możliwe, iż uroczyste wprowadzenie Arki na Syjon stało się corocznym obchodem (por. Ps $24 ; 78 ; 132$ ), rozbudowaną

28 "According to 1 Chr 15:26 the bearers of the ark were Levites but many scholars consider this to be a later interpretation of the less explicit 2 Sam 6:13. The ark was no longer transported by an ox-cart but was carried (see v 3), perhaps as a result of Uzzah's death. When the bearers of the ark had advanced six steps, a sacrifice was offered consisting of an ox and a fatted calf. In $1 \mathrm{Chr}(15: 26)$ this same sacrifice consists of «seven bulls and seven rams»”. A.A. Anderson, 2 Samuel (WBC 11) (Dallas: Word, Incorporated 2002) 105.

29 "David as king of Jerusalem would have become a priest of Yahweh. However, as a Yahwistic priest in the order of Melchizedek, David would have been prohibited from performing his duties explicitly reserved for the Aaronic priesthood. His status as a Melchizedekian priest would not have restricted him from leading in certain aspects of worship, and this he did with vigor". R.D. Bergen, 1, 2 Samuel (Logos Library System; The New American Commentary 7) (Electronic ed. Nashville: Broadman \& Holman Publishers 2001), 331; por. E.H. Merrill, "Royal Priesthood: An Old Testament Messianic Motif," BibSac 150 (1993) $50-61$.

30 Mikal jest tu już bardziej „córką Saula”, niż „żoną Dawida”, co podkreśla opozycję i przynależność Mikal do obozu wrogów Dawida. Por. Anderson, 2 Samuel, 106.

31 J. Lemański stwierdza: „Historia Dawida (1 Sm 16 - 2 Sm 5) ukazana na tle stopniowego upadku rządzącego Saula i jego potomków, uwydatnia walory polityczne i religijne nowego pretendenta do tronu i opowiada, w jaki sposób potrafił on po raz pierwszy w historii, zjednoczyć plemiona z północy (Izrael) i południa (Juda), osiągając idealne warunki do pełnego i niezależnego objęcia w posiadanie ziemi obiecanej przodkom. Ten sukces wymagał utrwalenia. 2 Sm 5 i 8 ukazuje polityczne zabiegi króla mające na celu umocnienie i scentralizowanie zdobytej władzy, natomiast 2 Sm 6-7 podaje jej religijne uzasadnienie”. J. Lemański, „Opowiadanie o Arce przymierza (1 Sm 4,1-7,1; 2 Sm 6) jako klucz do teologii Ksiąg Samuela”, Scriptura Sacra 11 (2007) 25.

32 Por. Anderson, 2 Samuel, 108. 
liturgią, która mogła stać się punktem wyjścia dla opisu tego wydarzenia przez autora $1 \mathrm{Krn}^{33}$.

Nieco inaczej przeto, niż w $2 \mathrm{Sm}$ te historie przedstawia $1 \mathrm{Krn}$, gdzie właśnie działalność liturgiczna Dawida stanowi ważny aspekt, który został rozwinięty w tej księdze ${ }^{34}$. Komentatorzy przypuszczają, iż obraz Dawida w Księdze Syracha, a zwłaszcza odniesienia do kultu i muzyki świątynnej pochodzą właśnie z $1 \mathrm{Krn}^{35}$. 1 Krn 15,1-16,3 przedstawia przygotowanie miejsca dla Arki Przymierza (15,1-3), ustanowienie odpowiedzialnych za przebieg liturgii $(15,4-24)$ oraz samo uroczyste przeniesienie Arki (15,25-29) i związane z tym świętowanie (16,1-3). Dawid posiadał już swój kompleks mieszkalny („domy”) i uznał za stosowne, aby sprowadzić do swej stolicy Arkę oraz przygotować dla niej święte miejsce - namiot, co wyraźnie nawiązuje do przenośnego sanktuarium na pustyni i roli Mojżesza ${ }^{36}$. Kronikarz podkreśla szczególną rolę lewitów, jako tych, którzy z woli Bożej mieli obowiązek transportowania Arki oraz pomocy kapłanom w posługach liturgicznych i wymienia również ich rody $(15,4-10)$. Wcześniejsza nieobecność lewitów jest tutaj również powodem niemożności pierwszego przetransportowania Arki (por. 1 Sm 6,6-10;

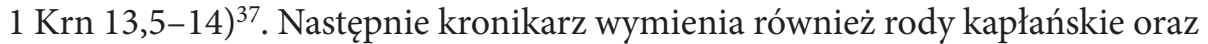
pojawia się Dawidowe wezwanie skierowane zarówno do kapłanów, jak i le-

33 Por. Anderson, 2 Samuel, 108.

34 Por. R. Petraglio, Il libro che contamina le mani: Ben Sirac rilegge il libro e la storia d'Israele (Theologia; 4) (Palermo: Augustinus Verlag 1993) 234.

35 Zob. np. : Oesterley, The Wisdom of Jesus the Son of Sirach or Ecclesiasticus, 320-321; V. Hamp, Sirach (Die Heilige Schrift in deutscher Übersetzung, Echter - Bibel 13; Würzburg 1952) 129; J.G. Snaith, Ecclesiasticus. Or the Wisdom of Jesus, Son of Sirach (The Cambridge Bible Commentary on The New English Bible, Cambridge: Cambridge University Press 1974) 234-235; Minissale, Siracide, 225; Skehan - Di Lella, The Wisdom of Ben Sira, 526; Petraglio, Il libro che contamina le mani, 235; Sauer, Jesus Sirach, 321; Demitrów, Quattro oranti nell'Elogio dei Padri (Sir 44-49), 309; B.M. Zapff, Jesus Sirach 25-51 (Kommentar zum AT mit der Einheitsübersetzung. Die Neue Echter Bibel 39; Würzburg 2010) 347-348; Marko, "David in the Wisdom of Ben Sira", 48; A. Tronina, 1 Księga Kronik. Wstęp, przekład z oryginału, komentarz (NKB ST X/1) (Częstochowa: Edycja św. Pawła 2015), 59.

36 "The buildings David erected for himself were a palace and other yet-unnamed structures. Details of these were not regarded as particularly important. The focus is on the place he had prepared for the ark of God and the tent he had pitched for it although details about the nature of this tent are not given (cf. 2 Sam 6:17). This must have been a new construction. The old Mosaic tabernacle was still at Gibeon (16:39; $2 \mathrm{Chr}$ 1:3; cf. $1 \mathrm{Kgs}$ 8:4). The term «place» often carries overtones of a holy place". J.A. Thompson, 1, 2 Chronicles (Logos Library System; The New American Commentary 9) (Electronic ed., Nashville: Broadman \& Holman Publishers 2001) 135.

37 Por. Tronina, 1 Księga Kronik, 288. 
witów, aby godnie przygotować się do świętych czynności przenoszenia arki i obrzędów kultycznych $(15,11-15)$. Dawid nakazał naczelnikom rodów lewickich, aby wyznaczyli grających na instrumentach i śpiewających psalmy: „Dawid polecił przywódcom rodów lewickich wyznaczyć spośród członków swych rodów śpiewaków, grających na poszczególnych instrumentach muzycznych: cytrach, lirach i cymbałach, tak aby rozbrzmiewał donośny głos radości" (1 Krn 15,16). O ile wcześniej król sam wyznaczył lewitów do posługi, o tyle kantorów mają ustanowić naczelnicy rodów ${ }^{38}$. Co ciekawe, urzędu kantorów nie ma w przepisach dotyczących różnych urzędów w przekazie deuteronomisty (por. Pwt 16,18-18,22), ani w kodeksie kapłańskim ${ }^{39}$. Stąd też Dawid, mając świadomość uzdolnień muzycznych poszczególnych rodów lewitów, jawi się jako biblijny inicjator śpiewu i muzyki liturgicznej ${ }^{40}$. Dalej w 16,4 kronikarz znów przekazuje inicjatywę samemu Dawidowi, który przeznacza lewitów do posługi wielbienia YHWH: „Ustanowił niektórych lewitów usługujących przed Arką YHWH, aby pomagali wspominać, wysławiali i wielbili Pana, Boga Izraela”. (1 Krn 16,4). To wszystko miało się dokonywać przez śpiew chóralny, jako integralną część kultu Izraela ${ }^{41}$. Lewici mieli przez swój śpiew „spowodować wspominanie" (זכר hifil) wielkich dzieł YHWH, lub też może to odnosić się do „przypominania” Bogu o Jego przymierzu z Izraelem ${ }^{42}$. Pozostałe dwa czasowniki oznaczają czynności kultyczne związane z wielbieniem Boga: „wysławiać” (ידה hifil), „wielbić” (הלל piel) ${ }^{43}$. Wszystkie te czynności są dokonywane w pobliżu ołtarza, gdzie na polecenie Boga wspomina się Jego święte imię (por. Wj 20,24; 2 Sm 18,18; Iz 12,4; Ps 45,18; 71,16; Tb 12,12), co wiąże się być może ze śpiewem hymnów dziękczynnych i wielbiących Boga ${ }^{44}$. 1 Krn 16,5-6 wymienia instrumenty muzyczne używane w kulcie przez lewitów - harfy, cytry i cymbały oraz trąby, używane stale przez kapłanów ${ }^{45}$. Dokonując podsumowania rządów, u schyłku życia Dawida, kronikarz znów przypomina o królewskiej

38 Por. R.L. Braun, 1 Chronicles (WBC 14) (Dallas: Word, Incorporated 2002) 190.

39 Tronina za I. Knohl, The Sanctuary of Silence, sugeruje, iż w świątyni panowało milczenie, por. Tenże, 1 Księga Kronik, 291; G.N. Knoppers, I Chronicles 10-29. A New Translation With Introduction and Commentary (New Haven - London: Yale University Press 2008) 633.

40 Por. Skehan - Di Lella, The Wisdom of Ben Sira, 526; Thompson, 1, 2 Chronicles, 137.

41 Por. Thompson, 1, 2 Chronicles, 140.

42 Por. Tronina, 1 Ksiega Kronik, 304.

43 Por. Thompson, 1, 2 Chronicles, 138.

44 Por. Braun, 1 Chronicles, 194; Tronina, 1 Księga Kronik, 304.

45 Kronikarz podkreśla, iż używanie instrumentów oraz śpiew stanowiły stały element obrzędów kultycznych; por. Knoppers, I Chronicles 10-29, 643. 
organizacji kultu związanej z posługą lewitów: „Cztery tysiące miało wychwalać YHWH za pomocą instrumentów, które [Dawid] polecił zrobić, aby były używane w czasie modlitwy”. (1 Krn 23,4). Mieli obowiązek „trwać nieustannie przed YHWH” oraz „sprawować pieczę nad Namiotem Spotkania, miejscem świętym i braćmi Aaronitami w służbie domu YHWH". (por. 1 Krn 23,31-32). Ta służba nie oznacza jedynie pracy fizycznej, pełnionej w przybytku, ale „rozciąga się na kult duchowy i staje się synonimem liturgii" ${ }^{46}$. Nie bez znaczenia jest fakt, iż kronikarz sporządza swe dzieło w epoce perskiej i chce wykazać, iż taki właśnie porządek służby świątynnej jest zakorzeniony w ustanowionej przez Boga monarchii Dawidowej. To, co było Bożym postanowieniem przekazanym za pośrednictwem pomazańca Bożego Dawida, jest wciąż aktualne w epoce Drugiej Świątyni.

\section{Liturgiczna działalność Dawida w Syr 47,8-10}

Liturgiczna działalność Dawida w Pochwale Ojców rozpoczyna się od zwrócenia uwagi mędrca na jego osobistą pobożność i odniesienie do Boga $(47,8)$, a następnie pojawiają się skutki tej postawy - w odniesieniu do religijnego wymiaru wspólnoty $(47,9-10)^{47}$. W 47,4-5 Syrach opowiada o walce Dawida z Goliatem oraz o innych zmaganiach, które okazały się zwycięskie dzięki wzy-

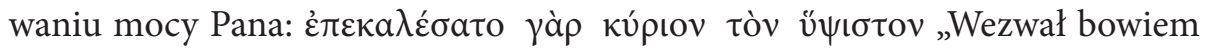
Pana Najwyższego" $(47,5)$. Są to konkretne sytuacje wskazujące na relację Dawida $z$ Bogiem, szukania oparcia w Jego pomocy i obecności ${ }^{48} .47,8$ uwypukla

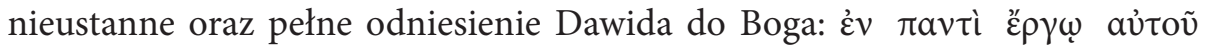

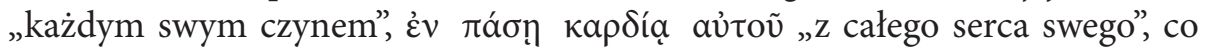
wydaje się być zamierzoną emfazą, kreślącą obraz idealnie pobożnego króla. Wprawdzie deuteronomista pokazuje zarówno żarliwą (por. 2 Sm 7,18-29), jak i pokorną (por. $2 \mathrm{Sm} \mathrm{12,20)} \mathrm{modlitwę} \mathrm{Dawida,} \mathrm{ale} \mathrm{nie} \mathrm{jest} \mathrm{ona} \mathrm{tak} \mathrm{przez} \mathrm{niego}$ eksponowana, jak w dziele Syracha ${ }^{49}$. Mędrzec z Jerozolimy nie chce ograniczać modlitewnej postawy Dawida jedynie do jakiś ważnych, czy trudnych wyda-

46 W 1 Krn następuje zmiana. Już nie sami kapłani, jak sugeruje Lb 18,5 sprawują piecze nad sanktuarium, ale również lewici, którzy posiadali wcześniej jedynie funkcje pomocnicze (por. Kpł 18,2-3). Wiąże się to ze zmianą, przejściem od „przybytku” Mojżesza do projektu świątyni zamierzonej przez Dawida, ale wybudowanej ostatecznie przez Salomona. Por. Tronina, 1 Księga Kronik, 390.

47 Por. Xeravits, "The Figure of David in the Book of Ben Sira”, 31.

48 Por. Demitrów, Quattro oranti nell'Elogio dei Padri (Sir 44-49), 311.

49 Por. Marko, "David in the Wisdom of Ben Sira", 41. 
rzeń, ale rozciąga ją na całe jego życie i zaangażowanie całej osoby ${ }^{50}$. Modlitewna postawa Dawida opisana w 47,8 wyraża się w konkretnych czynnościach.

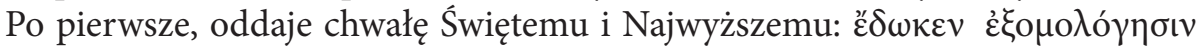

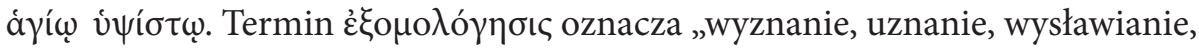
wielbienie”. Może wyrażać uznanie wobec człowieka (np. Syr 18,28), ale najczęściej odnosi się do czynności uwielbiania Boga, dziękowania Mu, sławienia Go i to na sposób publiczny: jest to czynność żywych (Syr 17,28); może towarzyszyć walce Izraela (2 Krn 20,22); ale zazwyczaj dotyczy modlitwy w świątyni, śpiewu i muzyki instrumentów oraz wyraża się w psalmach, np.: Syr 39,15; 1 Krn 25,3; Ps 41,5(LXX); Ps 94,2(LXX); Ps 99,4(LXX); Ps 146,7(LXX) ${ }^{51}$. Dalej, w Syr 47,8 mędrzec wyjaśnia, iż to uwielbienie dokonuje się zarówno w sło-

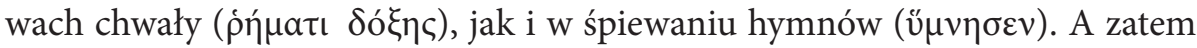
Dawid uwielbia Boga wypowiadanymi słowami pochwały, odkrywa działanie Boga w swoim życiu i składa Mu dziękczynienie ${ }^{52}$. Można zauważyć tu aluzję do słów proroctwa przypisywanych Dawidowi: „Oto ostatnie słowa Dawida. Wyrocznia Dawida, syna Jessego, wyrocznia człowieka wyniesionego wysoko, pomazańca Boga Jakuba, śpiewaka psalmów Izraela: «Duch Pański mówi przeze mnie i Jego słowo jest na moim języku»”. (2 Sm 23,1-2) ${ }^{53} .2$ Księga Kronik stawia Dawida razem z prorokami: „Postawił też lewitów w domu Pańskim z cymbałami, harfami i cytrami, według polecenia Dawida i Gada, «Widzącego» królewskiego, oraz proroka Natana, rozkaz bowiem pochodził od Pana za pośrednictwem Jego proroków." (2 Krn 29,25). W 47,8 pojawia się również wzmianka dotycząca śpiewania hymnów (ü $\mu \nu \eta \sigma \varepsilon v)$, można więc przypuszczać, iż mędrzec chciał przedstawić Dawida jako autora i wykonawcę psal-

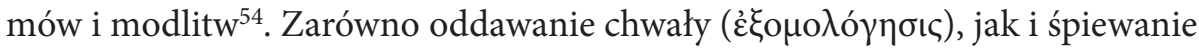

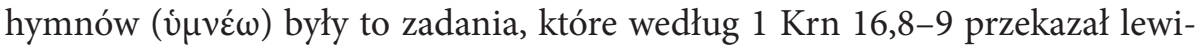
tom, Asafowi i jego braciom. A zatem Syrach wskazuje Dawida jako inicjatora kontynuowanej przez wieki liturgii chwały. Postawa Dawida jest motywowa-

50 Por. Demitrów, Quattro oranti nell'Elogio dei Padri (Sir 44-49), 312. Skehan - Di Lella, The Wisdom of Ben Sira, 526, zauważa w tym obrazie przesadę, która nie odpowiada osobie historycznego Dawida.

51 Wersja hebrajska proponuje tu użycie czasownika ידה (wysławiać), który posiada liczne konotacje kultyczne. Jest to między innymi jedna z czynności zleconych przez Dawida lewitom w 1 Krn 16,4. Znaczenie tego czasownika w wersji hebrajskiej Syr 47,8 przedstawia Demitrów, Quattro oranti nell'Elogio dei Padri (Sir 44-49), 312-314.

52 Por. Petraglio, Il libro che contamina le mani, 235.

53 "But in addition to all these other appellations, David was a prophet (cf. Acts 2:30). Thus David has now been portrayed throughout the books of Samuel as king, priest, and prophet". Bergen, 1, 2 Samuel, 465.

54 Por. Demitrów, Quattro oranti nell'Elogio dei Padri (Sir 44-49), 316. 
na miłością do Boga. Wersje hebrajska i syryjska akcentują tu siłę tej miłości:

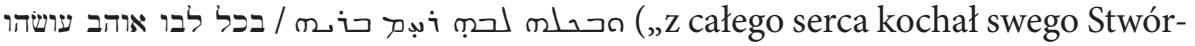
cę"), co jest wyraźnym odniesieniem do Pwt $6,4-5^{55}$. Jest to bardzo istotny aspekt przedstawienia osoby Dawida w dziele Syracha. Miłość Boga z całego serca zakłada i wyraża się w praktyce pierwszego przykazania dekalogu, czyli całkowitym odrzuceniu idolatrii. Wierność ta gruntuje się też w ciągłym powtarzaniu przykazań (por. Pwt 6,7), co sugeruje hebrajska wersja Syr 47,8: ובכל [יום] („i każdego dnia”); por. syryjska wersja Syr 47,9a: Wierność Bogu to jeden z największych walorów Dawida, a jednocześnie kryterium pozytywnej oceny króla przyjętej przez Syracha. W 49,4 tę pozytywną ocenę królów wiernych Bogu otrzymują jedynie Dawid, Ezechiasz i Jozjasz. Stąd Dawid jawi się tu jako przykład do naśladowania dla przyszłych pokoleńn ${ }^{56}$.

Syr 47,9-10 dotyczą konkretnych działań Dawida w organizacji życia religijnego w Jerozolimie, gdzie została sprowadzona Arka Przymierza. Działania Dawida tu przedstawione zostały zaczerpnięte z opisów kronikarza (por. 1 Krn $15,6 ; 16,4-6 ; 23,5)$ i dotyczą ustanowienia personelu kultycznego ${ }^{57}$. Na początku (9a) zostają wymienieni śpiewający psalmy ( $\psi \alpha \lambda \tau \omega \delta$ ov̀ $)$, którzy zostają po-

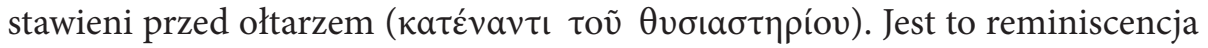
1 Krn 15,6: „I rzekł Dawid naczelnikom lewitów, aby ustanowili swoich braci śpiewakami przy instrumentach muzycznych: cytrach, harfach i brzmiących cymbałach, żeby radośnie głos podnosić”. O ile w 1 Krn śpiewaków i muzyków ustanowili na polecenie Dawida naczelnicy rodów, o tyle Syrach uwypukla działanie i wybór samego Dawida. Śpiewacy mają więc wykonywać psalmy i pieśni przy akompaniamencie instrumentu strunowego, co wynika $z$ terminu $\psi \alpha \lambda \tau \omega \delta$ ó $\varsigma$ („śpiewający psalmy”), który wraz z czasownikiem $\psi \alpha \lambda \tau \omega \delta \varepsilon ́ \omega$

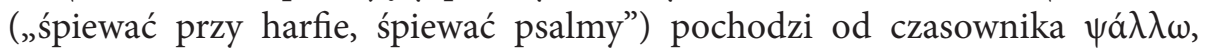
który, między innymi, znaczy „trącać, brząkać, pociągać palcami, szarpać”. W wersji hebrajskiej, która jest uszkodzona, na marginesie pojawia się zapis: קול מזמור נע ים („przyjemny dźwięk psalmu”), a termin מזמור pojawia się w nagłówkach wielu psalmów ${ }^{58}$. W 2 Sm 23,1 Dawid jest nazwany ונעים זמרות ישראל „Wspaniałym psalmistą Izraela”, co miałoby wskazywać na Dawidowe autor-

55 Por. Skehan - Di Lella, The Wisdom of Ben Sira, 526; Marko, "David in the Wisdom of Ben Sira”, 42; Demitrów, Quattro oranti nell'Elogio dei Padri (Sir 44-49), 317.

56 Por. Marko, "David in the Wisdom of Ben Sira", 42-43.

57 Por. Skehan - Di Lella, The Wisdom of Ben Sira, 526; Xeravits, "The Figure of David in the Book of Ben Sira", 32; Marko, "David in the Wisdom of Ben Sira", 43; Petraglio, Il libro che contamina le mani, 235.

58 Beentjes (ed.), The Book of Ben Sira in Hebrew, 84; por. Marko, "David in the Wisdom of Ben Sira", 43. 
stwo psalmów ${ }^{59}$. W samym tekście rękopisu B w 47,9 pojawia się pierwszeństwo instrumentów muzycznych נגינינות שיר ל] שני מזבח instrumenty muzyczne przed ołtarzem", które pojawiają się w 1 Krn 16,42 wymienione szczegółowo: "U Hemana i Jedutuna były przechowywane trąby i cymbały dla grających, i instrumenty towarzyszące pieśni Bożej." O ustanowieniu instrumentów informuje również $1 \mathrm{Krn}$ 23,5: „Odźwiernych było cztery tysiące, a cztery tysiące wychwalało Pana na instrumentach, które [Dawid] sprawił w tym celu" ${ }^{60}$. Słowo נגינות jest terminem technicznym oznaczającym bądź instrumenty sturunowe, bądź muzykę graną na instrumentach strunowych (נגינה) i pojawia się, między innymi, w nagłówkach psalmów (np.: Ps 4,1; 6,1; 54,1; 55,1; 67,1; 76,1) ${ }^{61}$. O mu-

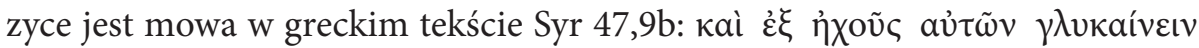

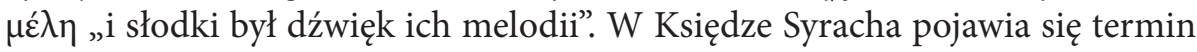
$\mu \varepsilon ́ \lambda o \varsigma$ na oznaczenie muzyki i pieśni: piękno muzyki przy słodkim winie $(32,6)$; muzyka z użyciem fletu i cytry $(40,21)$; autorzy muzyki i pieśni $(44,5)$; muzyka świątynna w czasie posługi arcykapłana Szymona $(50,18)$. Syr 47,9 przedstawia czasy, gdy nie było jeszcze świątyni w Jerozolimie. Muzycy ustanowieni przez Dawida pełnią jednak posługę w miejscu kultu, w pobliżu Arki Pana, na co

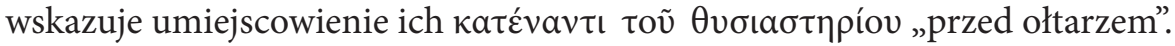

O ile w tekście hebrajskim, w rekonstrukcji 9b kompozycja muzyki i jej instrumenty odnoszą się do samego Dawida62 (המזמור לנב]לים תיקן dźwięk psalmów dla harf ustanowił”), o tyle tekst grecki uwypukla piękno muzyki ustanowionych przez Dawida lewitów ${ }^{63}$. Chodzi zatem o ustanowienie stałej, zorganizowanej posługi śpiewaków i muzyków uczestniczących czynnie w kulcie i przyczyniających się do jego piękna, a inicjatorem tego przedsięwzięcia ma być sam król, co dodaje mu powagi i gwarantuje stałośćc ${ }^{64}$. W taki sposób zostaje ustanowiona „orkiestra” świątynna lewitów, obecna również w Drugiej Świątyni (por. 1 Krn 15,16; Ne 12,27). Opis organizacji liturgii Jerozolimskiej w opisie Syracha nie skupia się zaskakująco na kulcie ofiar, ale na „kulcie duchowym" - chwale i uwielbieniu YHWH poprzez śpiew psalmów i piękno mu-

59 Por. Petraglio, Il libro che contamina le mani, 235; Xeravits, "The Figure of David in the Book of Ben Sira”, 32; Możliwe tłumaczenie tego wyrażenia: „Umiłowany w pieśniach Izraela"; więcej na ten temat: Bergen, 1, 2 Samuel, 465.

60 Por. Skehan - Di Lella, The Wisdom of Ben Sira, 526.

61 Por. Oesterley, The Wisdom of Jesus the Son of Sirach or Ecclesiasticus, 320; Demitrów, Quattro oranti nell'Elogio dei Padri (Sir 44-49), 323.

62 Wymieniona tu harfa (נבל) stanowi instrument nazwany w 2 Krn 29,25-26 wraz z cymbałami i cytrą „instrumentami Dawida” (כלי דויד).

63 Por. Demitrów, Quattro oranti nell'Elogio dei Padri (Sir 44-49), 322.

64 Por. Skehan - Di Lella, The Wisdom of Ben Sira, 526. 
zyki. Podobnie nie ma tu mowy o kapłanach składających ofiary, a o posługujących lewitach - muzykach ${ }^{65}$.

Syr 47,10 dotyczy organizacji świąt oraz codziennego porządku w liturgii. Najpierw zostaje nadany specjalny charakter świętom, które odróżniają się od

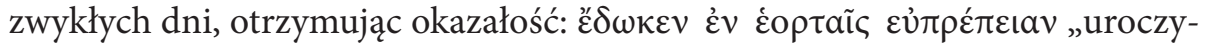

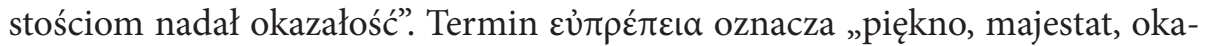
załość" i dotyczy domu Pana (Ps 25,18 LXX), Syjonu (Ps 49,2 LXX), a nawet jest „odzieniem” Pana (Ps 92,1; 103,1 LXX). A zatem piękno, okazałość świątecznych celebracji miał odzwierciedlać piękno i potęgę samego Boga i głosić Jego chwałę. Piękno zostało połączone dobrą organizacją czasu i ciągłością kultu. 47,10bc mówi o uporządkowaniu pór aż do szczegółów, aby wychwalali święte

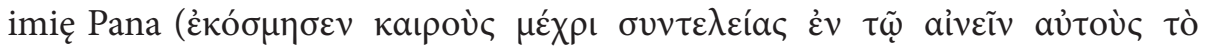
ä co przekazuje nam kronikarz: stawanie przed Panem $\mathrm{z}$ uwielbieniem rano i wieczorem, składanie ofiar w ilości zależnej od święta (por. 1 Krn 23,30-31), co było kontynuowane w świątyni wybudowanej przez Salomona (por. 2 Krn 8,14 ) oraz w świątyni po wygnaniu babilońskim (por. Ne 12,24) ${ }^{66}$. Czasownik

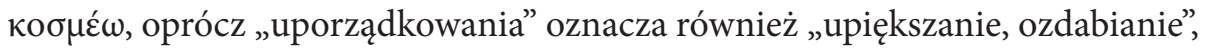
co dotyczy wszystkich szczegółów czasu i przestrzeni kultu Bożego. W Księdze

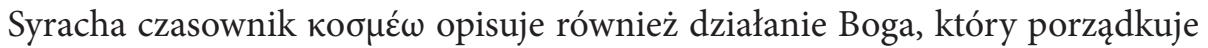
i upiększa dzieło stworzenia (por. Syr 16,27; 42,21). A wszystko to miało służyć

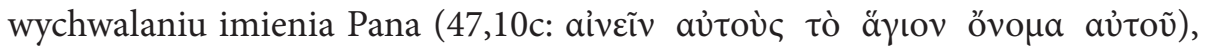
to znaczy wysławianie samego Boga, co szczególnie zauważa się w modlitwie psalmów (np. Ps 134,1.3; 144,2; 148,5.13; 149,3 LXX). A zatem liturgia i obrzędy kultu mają mieć w sobie piękno, harmonię, porządek samego Stwórcy. Celebracje nie tylko miały wspominać dzieła Boga, Jego zbawcze interwencje w przeszłości, ale ogłaszać Jego chwałę i moc w teraźniejszości, sławić Jego imię, przez co miały się stawać „kanałami łaski Pana”67.

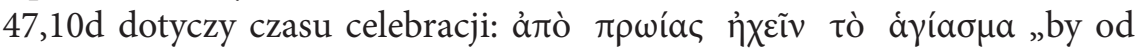
świtu rozbrzmiewał przybytek". Psalmy posiadają wzmianki o nieustannym przebywaniu tam lewitów, którzy czuwali w nocy, aby od świtu wysławiać Pana (por. Ps 56,9; 118,62; 133,1 LXX) ${ }^{68}$. Tekst grecki nie określa dokładnie rodzaju porannych modlitw, sugerując jedynie, iż był to śpiew i muzyka, czasownik

65 Por. Demitrów, Quattro oranti nell'Elogio dei Padri (Sir 44-49), 326.

66 Por. Skehan - Di Lella, The Wisdom of Ben Sira, 526; Petraglio, Il libro che contamina le mani, 235.

67 Por. Demitrów, Quattro oranti nell'Elogio dei Padri (Sir 44-49), 327.

68 Por. Skehan - Di Lella, The Wisdom of Ben Sira, 526; Marko, "David in the Wisdom of Ben Sira”, 43. Tekst hebrajski sugeruje, iż modlitwa rozbrzmiewała jeszcze przed świtem: 
$\eta\rceil \chi \varepsilon ́ \omega$ oznacza „zabrzmieć, rozbrzmieć, wydawać dźwięk, rozlegać się”. W tekście hebrajskim pojawia się słowo משפט „przykazanie”, co sugeruje treść porannej modlitwy jako proklamacji przykazań. Zadaniem kultu jest więc dać poznać, co jest wolą Pana wobec człowieka. Człowiek ma usłyszeć, pamiętać przykazania, aby je zachować, bo w nich jest życie. Wierność przykazaniom prowadzi do pełnej miłości Boga, Jego prymacie w życiu człowieka, co Syrach uwypuklił w przedstawieniu postaci Dawida $(47,8)^{70}$.

Obrzędy dotyczyły codziennych godzin ofiar i modlitw, specjalnych obchodów podczas świąt i uroczystości, którym towarzyszył szczególnie uroczysty śpiew i muzyka. Nie wiadomo jednak do końca, czy to, co przekazuje zarówno kronikarz, jak i Syrach, jest faktycznym opisem liturgii czasów Dawida, czy też chodzi tu bardziej o jego inicjatywę, która z czasem doprowadziła do rozkwitu liturgii świątynnej ${ }^{71}$. Być może więc tradycja Dawidowa w kwestiach liturgicznych przetrwała do czasów Drugiej Świątyni, a zarówno kronikarz, jak i Syrach stają się jej spadkobiercami i kontynuatorami ${ }^{72}$. Nie bez przyczyny Pochwała Ojców znajduje swój „szczyt” w opisie posługi kapłańskiej arcykapłana Szymona. Przez powtarzanie się aż piętnastu terminów w kultycznym opisie Dawida i Szymona, mędrzec łączy te dwie postaci i wskazuje na ciągłość ustanowionego kultu:

\begin{tabular}{|c|c|}
\hline Dawid $(47,8-10)$ & Szymon $(50,1-21)$ \\
\hline 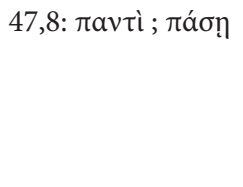 & 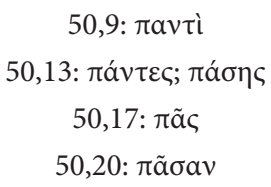 \\
\hline 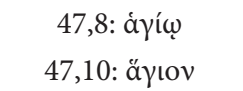 & 50,11: áyíov \\
\hline
\end{tabular}

[ר] לפני בק. Por. Oesterley, The Wisdom of Jesus the Son of Sirach or Ecclesiasticus, 321; Demitrów, Quattro oranti nell'Elogio dei Padri (Sir 44-49), 331-332.

69 Zob. przypis 24.

70 Por. Demitrów, Quattro oranti nell'Elogio dei Padri (Sir 44-49), 336-337.

71 Smend uważa, iż sadokici w czasach Dawida nie przejawiali gorliwości i byli niedbali w służbie Bożej, stąd też radykalne posunięcia Dawida w kwestii kultu. Smend, Die Weisheit, 451.

72 Por. G.H. Box - W.O.E. Oesterley, “The Book of Sirach”, The Apocrypha and Pseudepigrapha of the Old Testament with Introductions and Critical and Explanatory Notes to the Several Books (ed. R.H. Charles) (Oxford 1913) 496. 


\begin{tabular}{|c|c|}
\hline 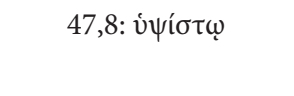 & 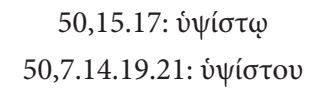 \\
\hline 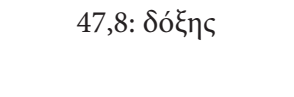 & 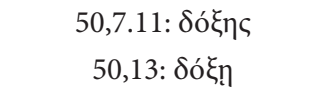 \\
\hline 47,9: ع̋ $\sigma \tau \eta \sigma \varepsilon \nu$ & 50,12: $\dot{\varepsilon} \sigma \tau \grave{\omega} \varsigma$ \\
\hline 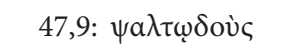 & 50,18: $\psi \alpha \lambda \tau \omega \delta$ ò̀ \\
\hline 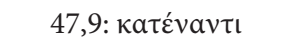 & 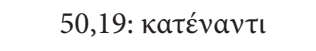 \\
\hline 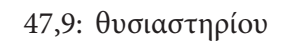 & 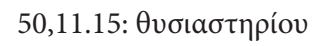 \\
\hline 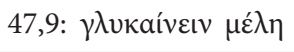 & 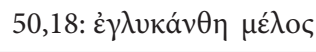 \\
\hline 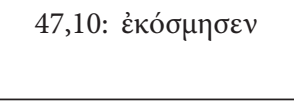 & 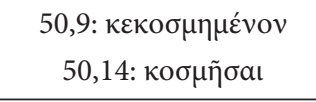 \\
\hline 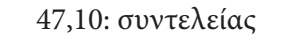 & 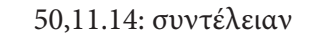 \\
\hline 47,10: aìvẽ̃ & 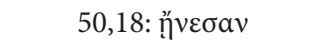 \\
\hline 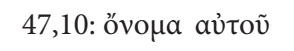 & 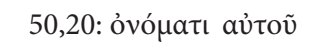 \\
\hline 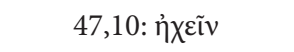 & 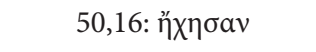 \\
\hline 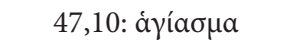 & 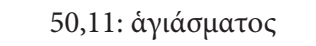 \\
\hline
\end{tabular}

Przedstawienie Dawida jako inicjatora liturgii Jerozolimskiej w Pochwale Ojców posiada wyraźne odniesienia do wcześniejszych przedstawień Dawida, zwłaszcza do relacji kronikarza. Dawid w swojej trosce o dom i chwałę Pana jawi się jako człowiek pełnego zaangażowania i troski. Opis Syracha wykazuje, że Dawid jako król jest przede wszystkim „człowiekiem kultu”73. Jednak koncepcja Syracha nie zatrzymuje się na kopiowaniu przekazu kronikarza. Przez taki obraz Dawida, Syrach wydaje się łączyć początki kultu obecne w przedstawieniu postaci Aarona (por. Syr 45,6-22) z kultem swoich czasów, reprezentowanym przez arcykapłana Szymona (por. Syr 50,1-21 ${ }^{74}$. W czasach Syracha nie było już monarchii, a dynastia Dawidowa nie była już widocznym znakiem przymierza między Bogiem i Izraelem. To miejsce po wygnaniu babilońskim przejęła świątynia w Jerozolimie i stający na jej czele arcykapłan - pośrednik

73 Por. Petraglio, Il libro che contamina le mani, 236.

74 Por. Petraglio, Il libro che contamina le mani, 236; Sauer, Jesus Sirach, 320. 
między Bogiem i ludem. Uwypuklenie kultycznej roli Dawida w jego panowaniu jest więc świadomym zabiegiem mędrca z Jerozolimy. Dokonuje on w ten sposób aktualizacji postaci Dawida do swoich czasów i stawia jako wzór liturgicznej gorliwości zarówno dla Żydów swoich czasów, jak i dla potomnych. Dawid jest przedstawiony jako „ogniwo łańcucha”, który prowadzi do czasów współczesnych mędrcowi z Jerozolimy ${ }^{75}$. Ta aktualizacja dochodzi do pełni w osobie arcykapłana Szymona (Syr 50,1-21), który swoją osobą i działaniem realizuje to, kim Dawid był w przeszłości.

\section{Bibliografia}

Anderson A.A., 2 Samuel (WBC 11) (Dallas: Word, Incorporated 2002).

Beentjes P.C., (ed.), The Book of Ben Sira in Hebrew. Text Edition of All Extant Hebrew Manuscripts and a Synopsis of All Parallel Hebrew Ben Sira Texts (VT.S 68; Leiden-New York-Köln: Brill 1997).

Bergen R.D., 1, 2 Samuel (Logos Library System; The New American Commentary 7) (Electronic ed. Nashville: Broadman \& Holman Publishers 2001).

Box G.H.-Oesterley W.O.E., "The Book of Sirach", The Apocrypha and Pseudepigrapha of the Old Testament with Introductions and Critical and Explanatory Notes to the Several Books (ed. R.H. Charles) (Oxford: Clarendon Press 1913) 268-517.

Calduch-Benages N.-Ferrer J.-Liesen J. (ed.), La Sabiduría del Escriba. Edición diplomática de la version siriaca del libro de Ben Sira segúnel Códice Ambrosiano, con tracucción española e inglesa / Wisdom of the Scribe. Diplomatic Edition of the Syriac Version of the Book of Ben Sira according to Codex Ambrosianus, with Translations in Spanish and English (Biblioteca Midrásica 26; Estella: Editorial Verbo Divino 2003).

Ciecieląg J., Żydzi w okresie drugiej świątyni 538 przed Chr. - 70 po Chr. (Kraków: Universitas 2011).

Demitrów A., Quattro oranti nell'Elogio dei Padri (Sir 44-49). Studio dei testi e delle tradizioni (Opolska Biblioteka Teologiczna 124; Opole 2011).

Di Lella A.A., The Hebrew Text of Sirach. A Text-Critical and Historical Study, (StCL 1; London-Paris: Mouton \& Co. 1966).

Drawnel H., "Władza arcykapłana w Izraelu we wczesnym okresie hellenistycznym: pomiędzy historią a kapłańską ideologią dydaktyczną", Polityka a religia (eds. P. Jaroszyński et al.) (Lublin 2007) 297-319.

Hamp V., Sirach (Die Heilige Schrift in deutscher Übersetzung, Echter - Bibel 13; Würzburg: Echter Verlag 1952).

Hartom E.S., $h$ i wnim hsprim bn sir' mtrgm b lqw wmpršr (Tel Avi 1963).

Harvey J.D., „Toward a Degree of Order in Ben Sira’s Book”, ZAW 105 (1993) 52-62.

75 Por. Xeravits, “The Figure of David in the Book of Ben Sira”, 36. 
Jüngling H.W., "Der Bauplan des Buches Jesus Sirach", Den Armen eine frohe Botschaft. FS für Bischof Franz Kamphaus zum 65. Geburtstag (eds. J. Hainz-H.W. Jüngling-R. Sebott) (Frankfurt a/M: De Gruyter 1997) 89-106.

Kearns C, The expandet Text of Ecclesiasticus. Its Teaching on the future Life as a Clue to its Origin, A doctoral Dissertation presented to the Pontificial Biblical Commision (Roma 1951).

Knoppers G.N., I Chronicles 10-29. A New Translation With Introduction and Commentary (New Haven-London: Yale University Press 2008).

Lee T.R., Studies in the Form of Sirach 44-50 (SBL Dissertation Series 75; Atlanta 1986).

Lemański J., „Opowiadanie o Arce przymierza (1 Sm 4,1-7,1; 2 Sm 6) jako klucz do teologii Ksiąg Samuela", Scriptura Sacra 11 (2007) 5-31.

Marböck J., "Structure and Redaction History in the Book of Ben Sira. Review and Prospects", The Book of Ben Sira in Modern Research. Proceedings of the First International Ben Sira Conference 28-31 July 1996, Soesterberg, Netherlands (ed. P.C. Beentjes) (Berlin-New York, NY 1997) 61-79.

Marko M., "David in the Wisdom of Ben Sira" SJOT 25/1 (2011) 29-48.

Merrill E.H., "Royal Priesthood: An Old Testament Messianic Motif," BibSac 150 (1993) 50-61.

Minissale A., Siracide (Ecclesiastico). Versione - Introduzione - Note (Roma: Edizioni Paoline 1980).

Oesterley, W.O.E., The Wisdom of Jesus the Son of Sirach or Ecclesiasticus. Revised Version with introduction and notes, (Cambridge: Cambridge University Press 1912).

Peters N., Das Buch Jesus Sirach oder Ecclesiasticus. Übersetzt und erklärt (Exegetisches Handbuch zum Alten Testament 25; Münster 1913).

Petraglio R., Il libro che contamina le mani: Ben Sirac rilegge il libro e la storia d'Israele (Theologia; 4) (Palermo: Augustinus Verlag 1993).

Piwowar A., "Syrach - obrońca prawowitego arcykapłanä, Od Melchizedeka do Jezusa Arcykapłana. Biblia o kapłaństwie (ed. D. Dziadosz) (Analecta Biblica

Lublinensia 5; Lublin: Wydawnictwo KUL 2010) 93-107.

Roth W., "On the Gnomic-Discursive Wisdom of Jesus Ben Sirach”, Semeia 17 (1980) 59-79.

Sauer G., Jesus Sirach / Ben Sira (ATD Apokryphen 1; Göttingen: Vandenhoeck \& Ruprecht 2000).

Segal M.S.,'The Evolution of the Hebrew Text of Ben Sira”, JQR 25 (1934-35) 91-149.

Segal M.S. (ed.), [Sēālèm] (Jerusalem: Bialik Institute 1972³).

Skehan P.W.-Di Lella A.A., The Wisdom of Ben Sira. A New Translation with Notes (AB 39; New York, NY: Doubleday 1987).

Smend R., Die Weisheit des Jesus Sirach erklärt (Berlin: Verlag von Georg Reimer 1906).

Snaith, J.G., Ecclesiasticus. Or the Wisdom of Jesus, Son of Sirach (The Cambridge Bible Commentary on The New English Bible, Cambridge: Cambridge University Press 1974).

Spicq C., L’Ecclésiastique (SB[PC]; Paris: Letouzey \& Ané 1951). 
Thompson J.A., 1, 2 Chronicles (Logos Library System; The New American Commentary 9) (Electronic ed., Nashville: Broadman \& Holman Publishers 2001).

Xeravits G.G., "The Figure of David in the Book of Ben Sira", Henoch 23 (2001) 13 , $27-38$.

Zapff B.M., Jesus Sirach 25-51 (Kommentar zum AT mit der Einheitsübersetzung. Die Neue Echter Bibel 39; Würzburg: Echter Verlag 2010).

Ziegler J. (ed.), Sapientia Iesu Filii Sirach (Septuagint: Vetus Testamentum graece auctoritate Societatis Göttingensis editium 12/2; Göttingen 1965, ${ }^{2} 1980$ ). 